\title{
The Prizes and Pitfalls of Large Capital Inflows in a Small Integrated Economy - Case of Croatia
}

\author{
Tomislav Globan
}

\begin{abstract}
This paper studies the macroeconomic and financial implications of large capital inflows in a small integrated economy by examining the case of Croatia and other EU new member states. Croatia was one of the countries that have experienced very large, dominantly debt inflows in the pre-crisis period. The question of implications of capital inflows is an important one, due to the fact that they have created dangerous macroeconomic imbalances, along with policy and prudential challenges for the policy holders. The analysis has shown that capital inflows positively impacted economic growth in the pre-crisis period and accelerated the development of the financial system in Croatia and EU NMS as well, but also fueled higher inflation rates, worsened current account balances, increased the indebtedness of countries and appreciated real exchange rates, which created severe policy challenges when the crisis hit. The contribution of the paper is reflected in emphasizing the importance of differentiating between types of foreign financing, given that short-term debt flows provide more exposure to potentially harmful macroeconomic and financial imbalances than long-term equity financing.
\end{abstract}

Index Terms-Capital inflows, economic and financial implications, EU new member states, small integrated economy.

\section{INTRODUCTION}

With the development and expansion of financial globalization and liberalization, capital flows have made capital more accessible to emerging and developing countries. This resulted in a surge in global capital flows during the 1990s and pre-crisis 2000s, which reached hitherto unprecedented levels. New member states of the European Union (EU NMS - Bulgaria, Croatia, Czech Republic, Estonia, Hungary, Latvia, Lithuania, Poland, Romania, Slovakia, and Slovenia) are among the groups of emerging countries that have attracted largest inflows of foreign capital over the past two decades. After years of relatively low capital inflows, the transition from planned to market economies in the early 1990s indicated the beginning of the period of much higher capital inflows. Gradual capital account liberalization that has accompanied the convergence and integration of transition countries into the EU has proved especially stimulating for capital inflows. However, capital inflows can have both beneficial and detrimental economic implications if the host country is a small open economy, which became painfully obvious after the onset of the financial and economic crisis.

This paper analyzes economic implications of large capital inflows in a small integrated economy by examining the case

Manuscript received November 13, 2013; revised March 17, 2014.

T. Globan is with the Faculty of Economics and Business, University of Zagreb, Croatia (e-mail: tgloban@efzg.hr). of Croatia and other EU NMS. Croatia was one of the countries that experienced very large capital inflows in the pre-crisis period, which fueled economic growth but also created dangerous macroeconomic imbalances, along with policy and prudential challenges for economic policy holders. The paper analyzes the impact of capital inflows on the main macroeconomic variables in Croatia (Section III), but also their effect on the stability of the domestic financial sector (Section IV). Prior to the analytical part of the paper, Section II carries out the overview of theoretical literature regarding the implications of capital inflows for the host economy.

\section{THEORETICAL ASSUMPTIONS AND LitERATURE REVIEW}

The inflow of foreign capital may have ambiguous macroeconomic and financial implications for the host economy. On the one hand, foreign capital can stimulate economic activity through increased domestic consumption and investment, and increase the export capacity of the country. Capital importing countries have lower levels of capital per worker, and access to international capital markets accelerates their economic growth and/or increases consumption levels. Capital inflows may increase economic growth rates by replacing domestic savings, thereby increasing the rate of capital accumulation [1]. Furthermore, foreign capital helps to finance the current account deficit, contributes to the development of domestic financial markets and improves the efficiency of the banking system. The presence of foreign investors in the domestic securities market increases the liquidity of the secondary market and the sophistication of financial services [2].

Foreign direct investment (FDI) is the type of flows that can potentially bring biggest benefits for the host country. FDI flows are associated with the ability to create new jobs, transfer of new knowledge, know-how, technology and management skills and generally improving the quality of human capital and labor, which spills over to other sectors of the economy [3], [4]. On the other hand, a large inflow of short-term and volatile types of capital can have a destabilizing effect on the real and financial sector and emphasize fundamental structural weaknesses of the domestic economy. A large increase in aggregate demand financed by foreign capital may lead to economic overheating, which can lead to significant inflationary pressures and/or instability of the exchange rate [5]. An increase in aggregate demand is a result of the rise in availability of capital which increases the level of lending in the country. This can be directed to the smoothing of consumption or investments in new projects, which in turn reduces domestic savings and creates a current account 
deficit. Monetary consequences of a balance of payments shock depend on the exchange rate regime. If the country has a floating exchange rate, capital inflows lead to nominal appreciation and the resulting current account deficit, while foreign reserves and money supply remain unchanged. But if the country has a fixed exchange rate, monetary authorities must increase the money supply, or reduce domestic interest rate, and accumulate foreign exchange reserves in order to maintain a fixed exchange rate [6].

Nominal appreciation of the exchange rate induced by capital inflows, accompanied by inflationary pressures, results in the appreciation of the real exchange rate and a decrease in the country's competitiveness. This is particularly the case if the consumption is predominantly focused on non-tradable goods. Given that their total supply is limited by the domestic supply, an increase in demand leads to an upward pressure on prices, which appreciates the real exchange rate and harms the domestic economy as it makes exports more expensive and adversely affects sectors that are competing with foreign competition due to cheaper imports.

If capital persistently flows in large volumes and if their composition is unfavorable (i.e. if they are dominated by debt flows), this further complicates the implementation of domestic macroeconomic policies and contributes to greater economic vulnerabilities of the economy. This often leads to the conflict of policies since policy makers are trying to achieve conflicting economic objectives - e.g. inflation targeting and exchange rate targeting with liberalized capital account - which leads to the "impossible trinity" [2].

Capital inflows can have strong negative implications for the financial sector of the host country and create potentially dangerous vulnerabilities in the sector, especially if the market is shallow, illiquid and volatile. If large capital inflows result in the overheating of the economy, a large credit expansion will follow, which can put the domestic banking sector in a very vulnerable position, with pronounced maturity and currency mismatches in balance sheets of banks, which could lead to a banking crisis in the event of a sudden stop of capital inflows [5], [7], [8]. This particularly applies to countries that suffer from the "original $\sin$ ", i.e. countries that are not able to borrow long-term in the domestic currency, which means they must borrow either short-term or in the foreign currency.

On the other hand, the growing presence of foreign investors should deepen the domestic financial market, improve the diversification of the investor base and increase market liquidity. Markets with diversified investor base should exhibit lower volatility in asset prices and a higher level of liquidity than markets with one dominant group of investors. Furthermore, the demand by foreign investors encourages the development of new financial instruments, which facilitates better management and allocation of market risk. Deeper and more liquid markets that come with a wider range of investment opportunities, on the other hand, further attract new investors [9]. Reference [10] emphasizes that the risks associated with the inflow of foreign capital are more evident in transition economies with slow and insufficient institutional development, especially in the legal and financial systems, as was the case in almost all EU NMS. With the acceleration of institutional development, the benefits of international financial integration grow, which in parallel increases their capacity to manage the risks entailed by large capital inflows.

\section{MACROECONOMIC IMPLICATIONS OF CAPITAL INFLOWS}

Since the beginning of the past decade until the onset of the financial and economic crisis, Croatia has marked relatively high economic growth rates. The average real GDP growth rate in the 2000-2008 period was 4.2 percent, which is two percentage points higher than in the EU-27, but also somewhat lower than average growth rates in other EU NMS (Fig. 1a). This economic growth had been primarily based on the expansion of domestic demand, which had been sustained by intensive inflows of foreign capital and sharp credit expansion. Fig. 1b reveals the positive correlation between average capital inflows and economic growth rates in Croatia and EU NMS during the 2000-2008 period.

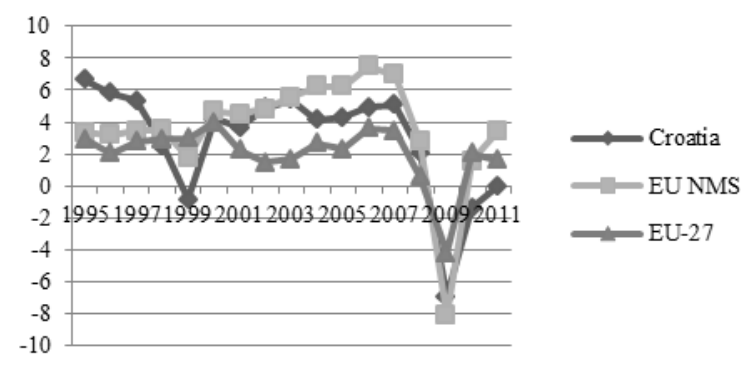

(a) Real GDP growth rates

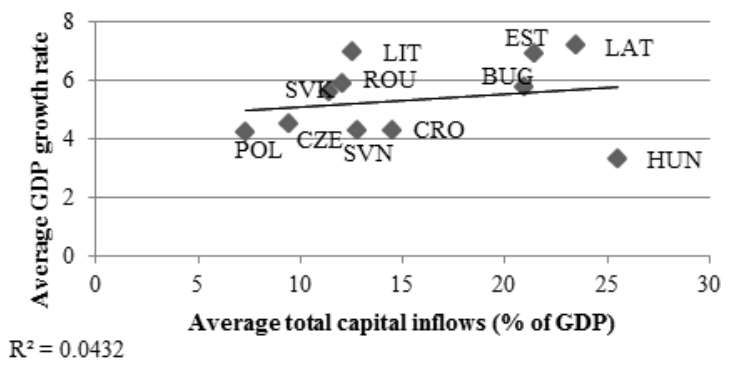

(b) Capital inflows vs. GDP growth (2000-2008)

Source: IMF - WEO Database (October 2012), author's calculations Fig. 1. Relationship between capital inflows and real GDP growth rates in Croatia and other EU NMS.

In Croatia, the share of the domestic demand in the formation of the GDP constantly rose and was slightly above the EU NMS average and significantly above the EU-27 average (Fig. 2a). Along with the domestic demand growth, as the main source of GDP growth, domestic investment in fixed capital had also been rising, but not at the same pace and on a lower level than in EU NMS (Fig. 2b).

In spite of notable inflatory pressures reinforced by the economic overheating due to pertinent increase in aggregate demand, Croatia successfully retained the price stability, with average annual inflation rate at the level of 3.3 percent in the 2000-2008 period, which is 1.7 percentage points lower than the average inflation rate in EU NMS (Fig. 3a). Price stability in terms of strong credit expansion has been preserved due to the reverse currency substitution at the earlier stages of transition and exchange rate stability and wage moderation in the later stages [2]. 


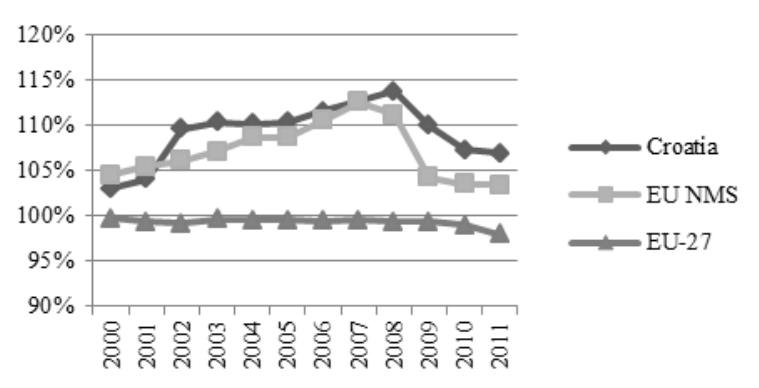

(a) Share of domestic demand in GDP

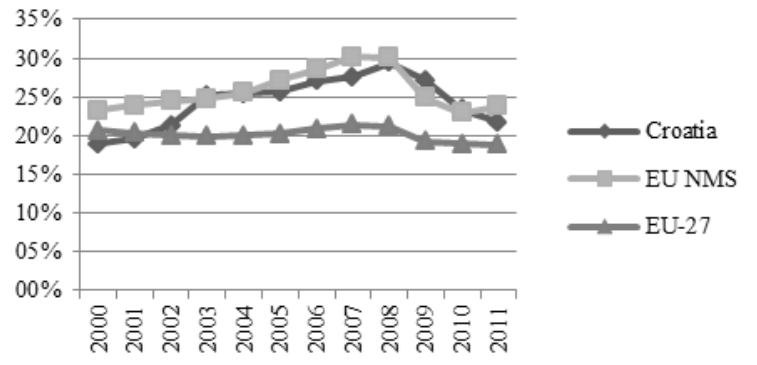

(b) Share of gross fixed capital formation in GDP

Source: Eurostat, author's calculations

Fig. 2. Shares of domestic demand and gross fixed capital formation in GDP in Croatia and other EU NMS.

Fig. $3 \mathrm{~b}$ indicates a relatively strong correlation between capital inflows and inflation rates in EU NMS. Countries with highest average inflows of capital (e.g. Hungary, Bulgaria, and Latvia) have experienced highest average inflation rates during the analyzed period.

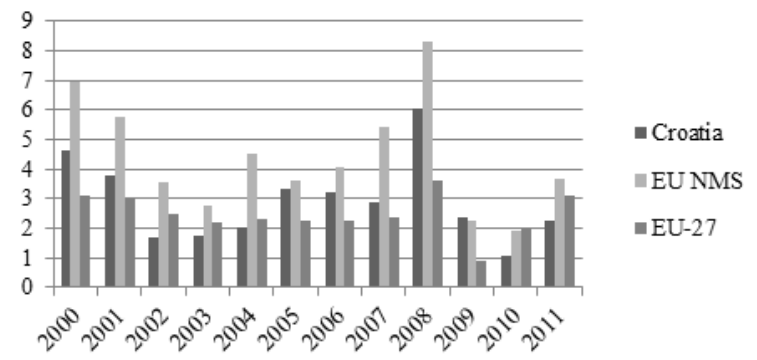

(a) Annual inflation rates

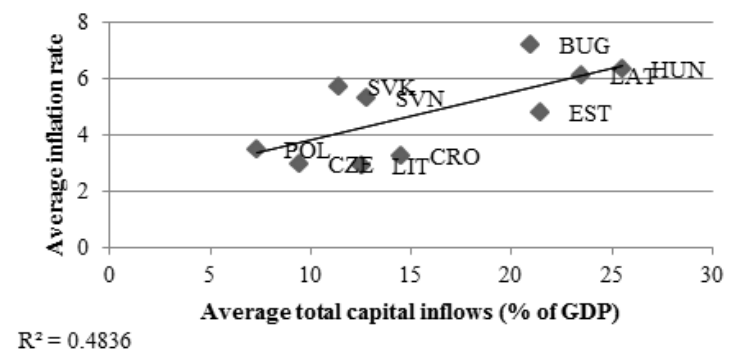

(b) Capital inflows vs. inflation rates (2000-2008)

Source: IMF - WEO Database (October 2012)

Note: Romania has been excluded from the sample due to extremely high inflation rates in the first half of 2000s.

Fig. 3. Relationship between capital inflows and inflation rates in Croatia and other EU NMS.

The increase in consumption and investment, and the resulting decline in domestic savings resulted in the worsening of the trade balance and increasing current account deficit, given that the domestic demand could not be satisfied by relatively weak domestic supply. The growth of domestic demand financed by foreign capital boosted imports, and with increasing capital inflows Croatia recorded growing current account deficits, which culminated in 2008 when they reached 9 percent of GDP (Fig. 4a).

Similar trends have been observed in EU NMS as well, with the average pre-crisis current account deficit exceeding Croatia's by two percentage points. Fig. $4 \mathrm{~b}$ clearly shows a relatively strong correlation between these two variables. The highest current account deficits have been recorded by countries with largest capital inflows - e.g. Latvia, Bulgaria, and Estonia. This positive relationship between the volume of capital inflows and current account deficits is specific to transition countries of Central and Eastern Europe, given that similar trends have not been observed in Asian and Latin American emerging countries [5].

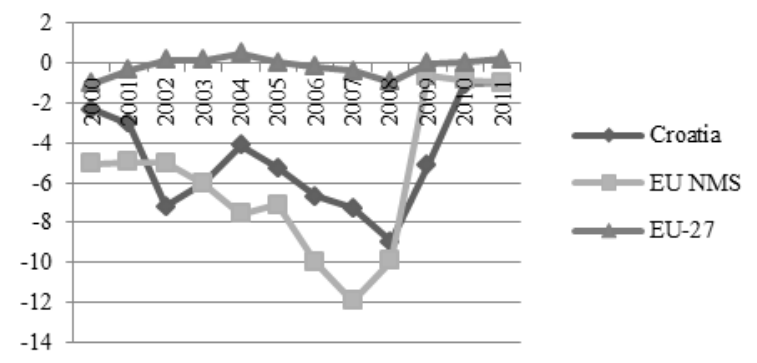

(a) Current account balance (\% of GDP)

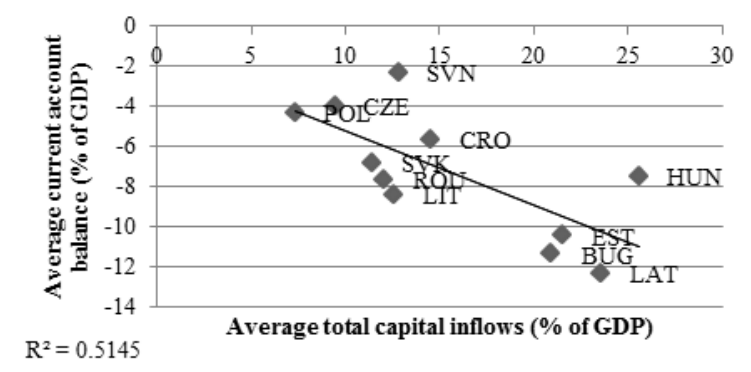

(b) Capital inflows vs. current account balance (2000-2008)

Source: IMF - WEO Database (October 2012), author's calculations Fig. 4. Relationship between capital inflows and current account deficits in Croatia and other EU NMS.

Sustainability of high current account deficits partly depends on the type of capital flows that finances it, i.e. the type of capital flows that dominates the financial account. Because of its long-term characteristics, inflow of direct equity investment is considered to be more stable and more reliable form of financing of external deficits than portfolio investments and debt capital flows, e.g. foreign bank loans. Debt flows have been the dominant type of capital inflows to Croatia since the country's independence, given they accounted for almost two-thirds of total capital inflows between 1993 and 2011 (Fig. 5). Two-thirds of accumulated foreign capital that has so far entered Croatia has directly created its foreign debt, which at the end of 2011 amounted to USD 59.2 billion (Fig. 6a). Foreign loans have been the dominant form of debt flows to Croatia. Sector analysis, however, reveals that this does not apply to all domestic sectors. Foreign loans have been the main channel of external debt creation for the corporate sector (Fig. 6d), a sector responsible for almost half of the total Croatian external debt 
(Fig. 6a).

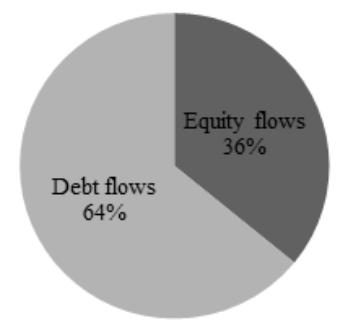

Source: CNB, author's calculations

Note: Debt inflows consist of the debt component of FDI (intracompany loans), the debt component of portfolio flows (investment in debt securities) and other investment. Equity inflows consist of equity direct investment, retained profits and portfolio investment in stocks and equity shares.

Fig. 5. Equity and debt inflows in Croatia, in percent of accumulated total capital inflows, 1993-2011.

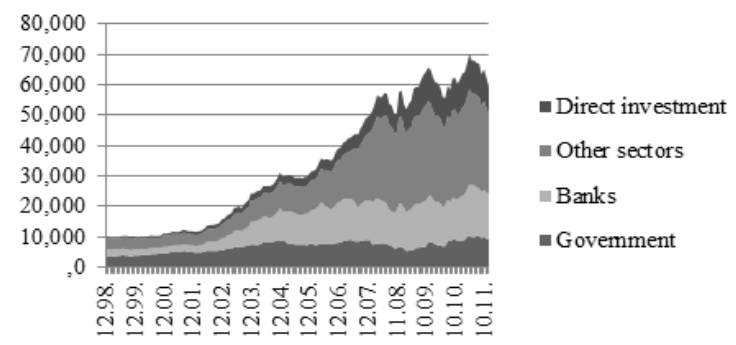

(a) Sectoral composition of foreign debt (mil. of USD)

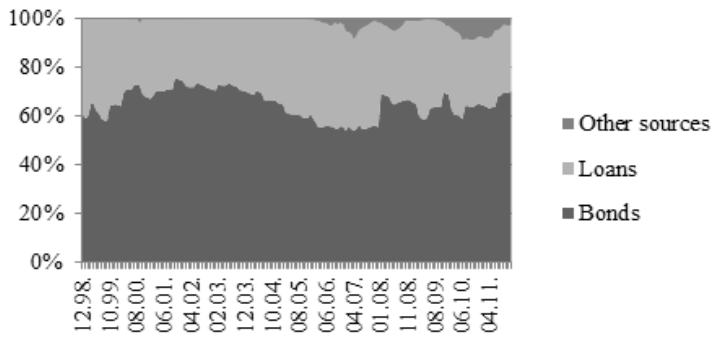

(b) Composition of foreign debt of the government

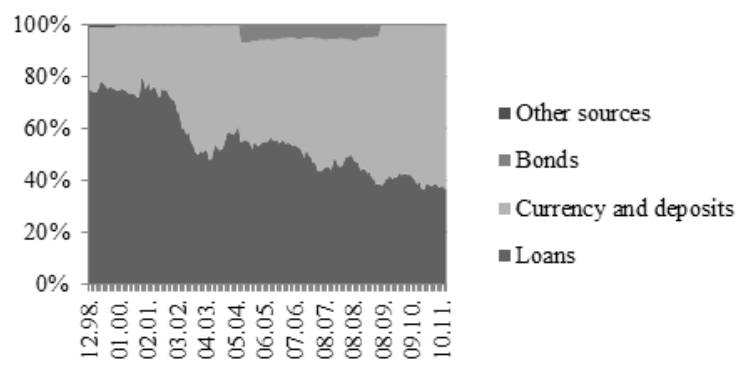

(c) Composition of foreign debt of banks

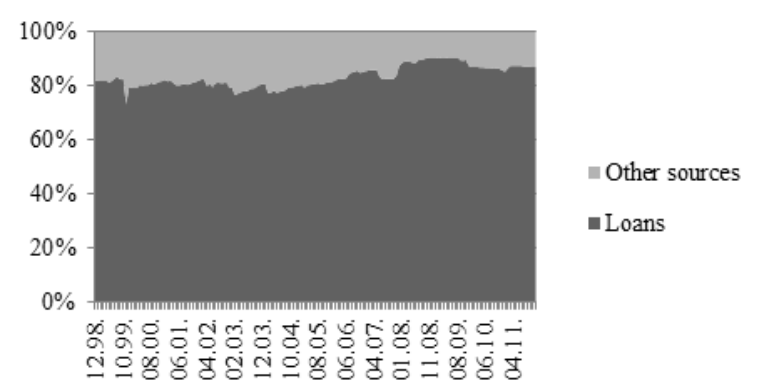

(d) Composition of foreign debt of enterprises

Source: CNB, author's calculations

Fig. 6. Sectoral composition of gross foreign debt of Croatia and channels of its creation, 1998:M12-2011:M12.
On the other hand, the government created its foreign debt primarily by issuing bonds (Fig. 6b), while the banking sector accumulated most of its foreign debt by an inflow of currency and deposits, with a constant decrease in the share of foreign loans (Fig. 6c). It should be noted that the debt component of FDI is also one of the components of a country's external debt. It includes loans from affiliated entities abroad and by the end of 2011 this component accounted for 15 percent of total external debt of Croatia (Fig. 6a). Most Croatian banks have borrowed from their foreign parent banks through this channel, which is why the external debt of the Croatian banking sector is underestimated by official statistics. External debt of banks has increased rapidly since 2003, in response to strong domestic demand for loans.

Croatian gross foreign debt exceeded the level of 100 percent of GDP for the first time in 2009, and by the end of 2011 it only slightly decreased. Fig. 7a indicates Croatia as one of the highest indebted EU NMS countries, along with Slovenia, Hungary, and Latvia. Fig. 7b shows a very strong positive relationship between the level of capital inflows and external debt stock in EU NMS. In other words, countries which have recorded lowest capital inflows in the pre-crisis period, like Poland and Czech Republic, have also accumulated lowest amounts of foreign debt.

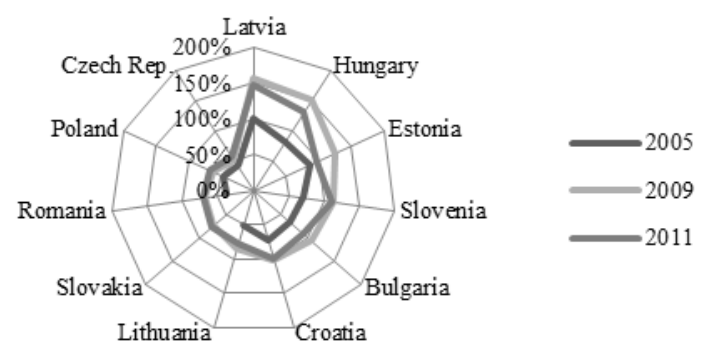

(a) Gross foreign debt (\% of GDP)

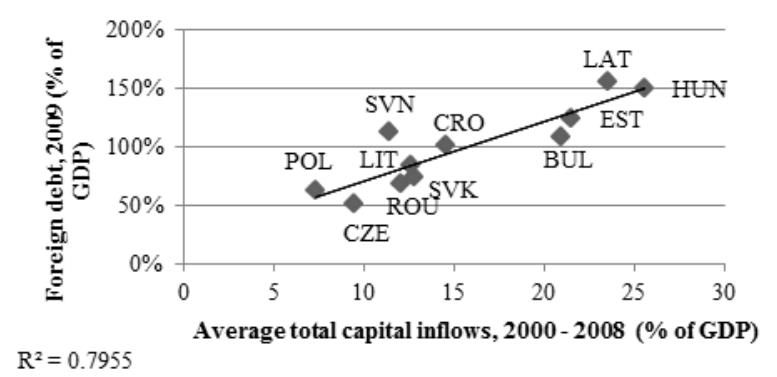

(b) Capital inflows vs. foreign debt

Source: Eurostat, CNB, author's calculations

Fig. 7. Relationship between capital inflows and foreign debt in Croatia and other EU NMS.

Intensive capital inflows exerted strong pressure on the appreciation of the real exchange rate of the domestic currency kuna. Croatian National Bank (CNB) had to resist appreciation pressures in order to prevent even more prominent deterioration in the trade balance and more intensive inflow of dangerous short-term debt capital, but also to preserve the exchange rate stability in terms of high level of euroization in the economy. For this purpose, CNB frequently used instruments of sterilization and imposed some restrictions on the free flow of debt capital and credit expansion, e.g. the marginal and special reserve 
requirements, mandatory purchase of treasury bills, the minimum required foreign currency claims, etc.

The real effective exchange rate of the Croatian kuna appreciated during the 2000s, but the trend was much weaker than in most EU NMS (Fig. 8a). Real appreciation in Croatia in the period between 2000 and 2008 amounted to 14 basis points (2010 as the base year). Only three countries - Latvia, Slovenia, and Poland - have recorded a lower level of appreciation, while in Slovakia it was more than 30 basis points higher than in Croatia (Fig. 8b).

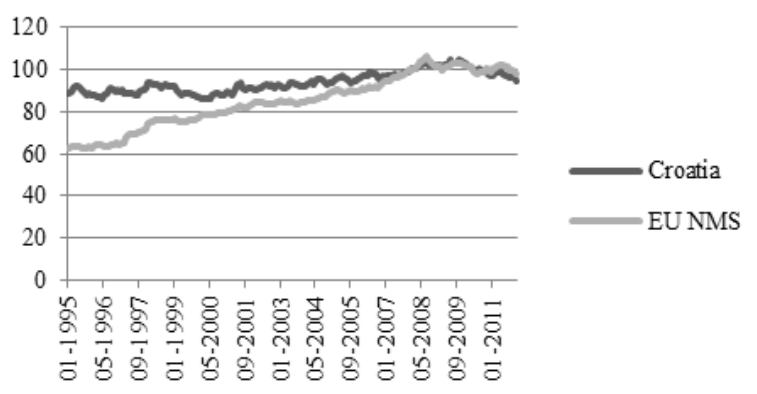

(a) 1995:M1-2011:M12

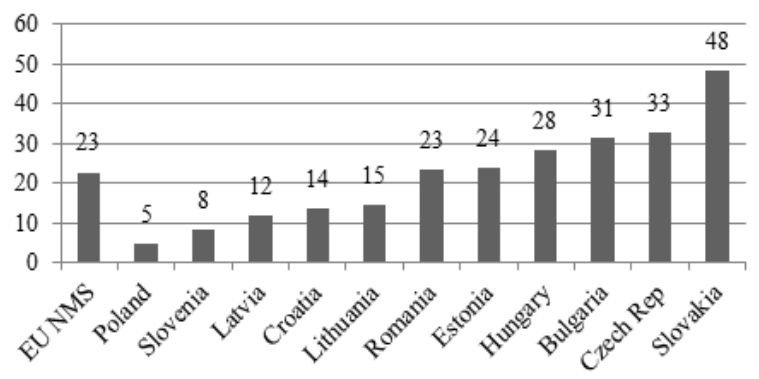

(b) Change in basis points (2000:M12-2008:M12)

Source: BIS, author's calculations

Fig. 8. Real effective exchange rate indices in Croatia and other EU NMS $(2010=100)$.

Sterilization measures of the central bank were necessary due to the high level of euroization of the economy in which the stability of the nominal exchange rate is an anchor of monetary policy and macroeconomic stability. The inflow of foreign capital has boosted the supply in the domestic foreign exchange market. In order to ease appreciation pressures on the exchange rate, CNB has bought foreign currency and thus has significantly increased its foreign reserves. The central bank then sterilized increased kuna liquidity using instruments of monetary policy to prevent the growth of money supply and the ensuing inflation.

Fig. 9a proves that the foreign reserves of $\mathrm{CNB}$ have consistently been rising over the past decade. By 2003, they doubled its 2000 level, and in 2006 and 2007 experienced strongest growth in the midst of strongest capital inflows. By 2005 , there were no significant differences in the dynamics of foreign reserves in the EU NMS with fixed or quasi-fixed exchange rates, and countries with floating exchange rate regimes. However, in parallel with the intensification of capital flows to EU NMS, the growth of foreign reserves significantly accelerated from 2006 onwards in countries with fixed exchange rates. This is not unexpected, given that, if the exchange rate is fixed, capital inflows put pressure on the exchange rate appreciation and the excess of foreign exchange must be absorbed by the central bank to maintain exchange rate stability, resulting in the increase in foreign reserves. Countries with floating exchange rates are not obliged to buy excess foreign exchange in the domestic market, which has reflected in a significantly slower growth of their foreign reserves (Fig. 9a).

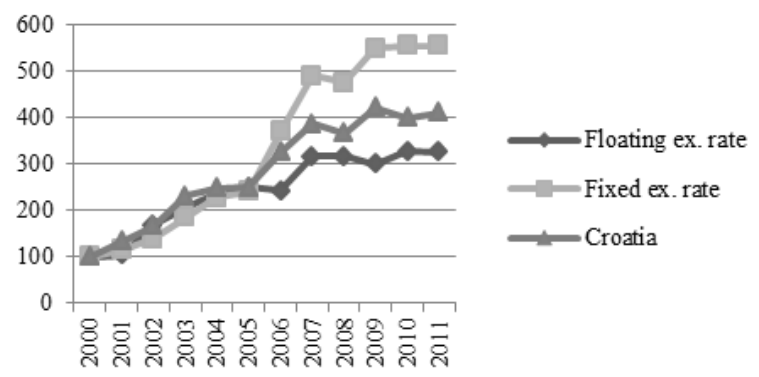

(a) Foreign reserves $(2000=100)$

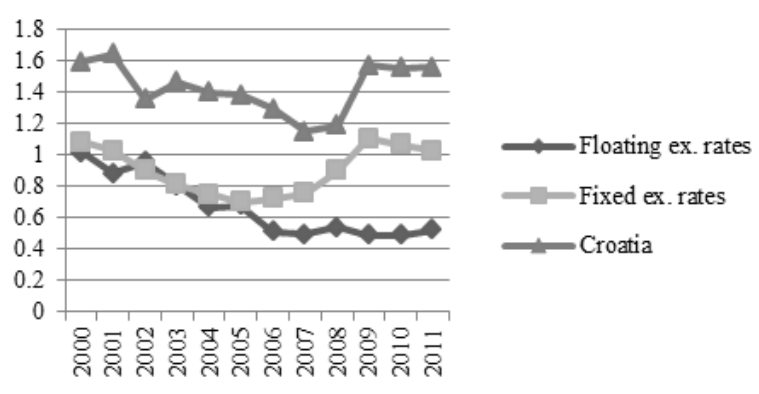

(b) Foreign reserves to money supply ratio

Source: World Bank - World Development Indicators, Eurostat, author's calculations

Note: Countries with floating exchange rates are Czech Republic, Poland, and Slovakia. Countries with fixed exchange rates are Bulgaria, Latvia, Lithuania, and Hungary (declared the transition to the floating exchange rate in 2008). Estonia and Romania have not been included due to extreme values of variables which significantly impact the averages.

Fig. 9. Foreign reserves and money supply in Croatia and other EU NMS, 2000-2011.

The sterilization in Croatia has resulted in a relatively high and stable foreign reserves to money supply ratio. Foreign reserves of $\mathrm{CNB}$ have consistently been higher than the domestic money supply (Fig. 9b), given that most of the money had been created by foreign exchange interventions by the central bank, which ranks Croatia among countries with the quasi-currency board. As expected, the ratio between reserves and money supply recorded a continuing decline in countries with a floating exchange rate, while in countries with fixed exchange rates it soared with the onset of intensive capital inflows.

Given that debt flows have been the dominant type of external financing for Croatian economic agents over the past two decades, the financial and economic crisis that hit the country in 2008 and continued in the coming years, left a strong impact on the sustainability of their future external financing. Due to the lack of liquidity in the domestic market, the government turned to foreign creditors to refinance maturing obligations in 2009 for the first time in five years, but now no longer at equally low interest rates as prior to the crisis. Yields on government bonds have increased in all EU NMS, reflecting the increase in risk premiums and CDS spreads, especially in countries with severe macroeconomic 
imbalances, e.g. Hungary, Romania, and Baltic states [11].

In terms of a difficult and costly access to foreign capital, the growth of Croatian external debt has significantly decelerated, but the ratio of external debt to GDP has risen from 85 percent in 2008 to 101 percent in 2009, primarily due to the significant contraction of the GDP (Fig. 7a), with similar trends in all new EU member states. The crisis-induced strong growth of foreign debt was recorded only in the banking sector, while the corporate sector slowed previously expansively growing external borrowing, thanks to the decline in foreign loans inflows, which was partially offset by issuing bonds on the international market.

During most of the last decade, CNB has been undertaking measures to curb the appreciation pressures on the exchange rate in terms of abundant capital inflows. Due to the significant slowdown in inflows caused by the financial crisis, CNB began to deal with the reverse exchange rate expectations. In terms of the lack of foreign currency inflows into the domestic market, the central bank had to fight against the depreciation pressures and, to that end, intervened in the foreign exchange market in late 2008 and early 2009, selling EUR 784 million [12], which reduced its foreign reserves, but also preserved the exchange rate stability (Fig. 9a).

Since the pre-crisis economic growth in Croatia had been based on strong growth in domestic demand, supported by inflows of debt capital from abroad, a sudden stop in capital inflows in 2009 was reflected in a sharp drop in economic activity (Fig. 1a), a decrease in the share of domestic demand and investment in GDP (Fig. 2), slowing inflation (Fig. 3a) and a strong current account adjustment evident in the reduction of its deficit (Fig. 4a). In terms of high external debt at around 100 percent of GDP and falling domestic demand, the new impetus to economic growth based on a new wave of inflows of debt capital is no longer viable nor possible. The new development strategy should be based on attracting equity capital flows, primarily of direct investment in the export sectors of the economy.

\section{FinANCIAL SECTOR IMPLICATIONS OF CAPITAL INFLOWS}

The inflow of foreign capital has had non-negligible influence on the development of the financial sector in Croatia, but it has also brought certain vulnerabilities into it. For example, volatile short-term capital inflows have caused instabilities in the foreign exchange market in 1998 and 1999, while the currency mismatch in the balance sheets of banks, which have borrowed in foreign currencies and granted loans in kunas, contributed to the emergence of two banking crises in the 1990s [2].

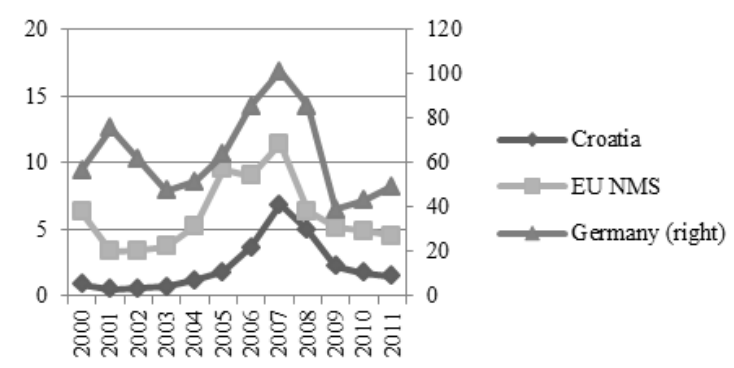

(a) Value of stocks traded (\% of GDP)

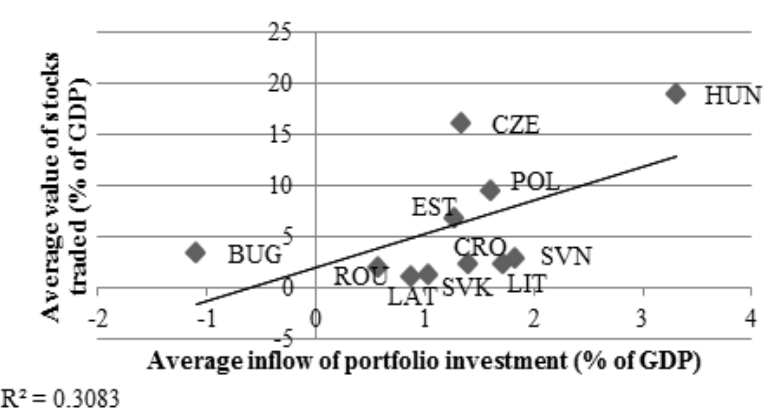

(b) Portfolio investment vs. value of stocks traded (2000-2008)

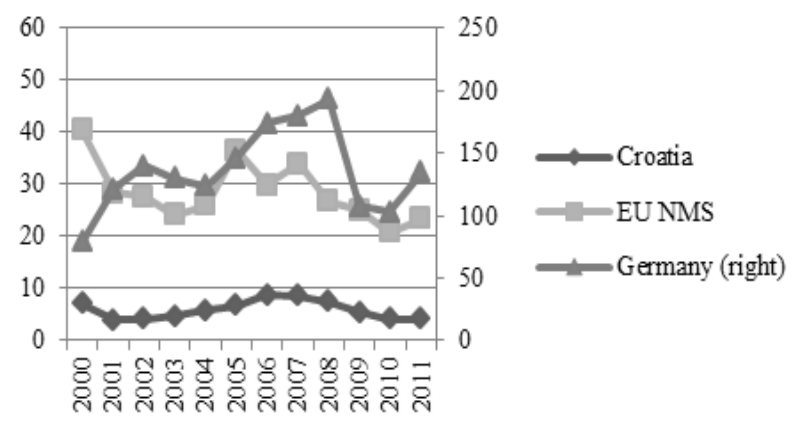

(c) Stock market turnover $(\%)$

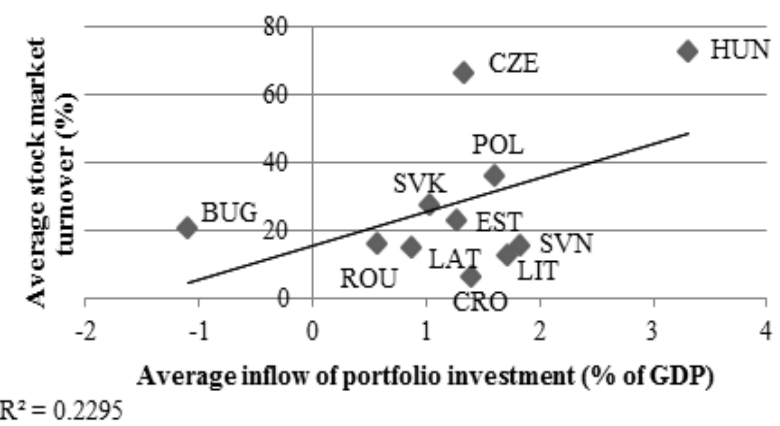

(d) Portfolio investment vs. stock market turnover (2000-2008)

Source: World Bank - World Development Indicators, author's calculations Fig. 10. Relationship between portfolio investment inflows and stock market indicators in Croatia and other EU NMS.

On the other hand, the entry of foreign capital into the Croatian banking system (over 90 percent of bank assets in Croatia is foreign-owned) has significantly improved the liquidity of the banking system. Moreover, a higher level of competitiveness has been achieved, along with increased efficiency and quality of products and services, increased strength of market competition, and further boost in the development of new products and services and of the interbank market [13].

As for the non-banking financial system, foreign capital inflows contributed to the development of institutional investors, foreign exchange markets, insurance markets, stock and bond markets and increased their depth, turnover, liquidity and market capitalization, both in Croatia and in other EU NMS [9], [10]. This is supported by Fig. 10b, which indicates a positive correlation between portfolio investments in EU NMS and the value of stocks traded on domestic stock markets. Moreover, Fig. 10d highlights the positive relationship between portfolio investment and stock market turnover in Croatia and EU NMS. Value of traded stocks has witnessed a strong rise, in parallel with the increase in equity portfolio investment inflows, but has been lower on average 
than in EU NMS throughout the analyzed period, and significantly lower than the traded value on the Frankfurt Stock Exchange as a benchmark European stock market (Fig. 10a). Similar trends can be observed in the stock market turnover, where the Croatian market falls short of the German and EU NMS markets even more (Fig. 10c).

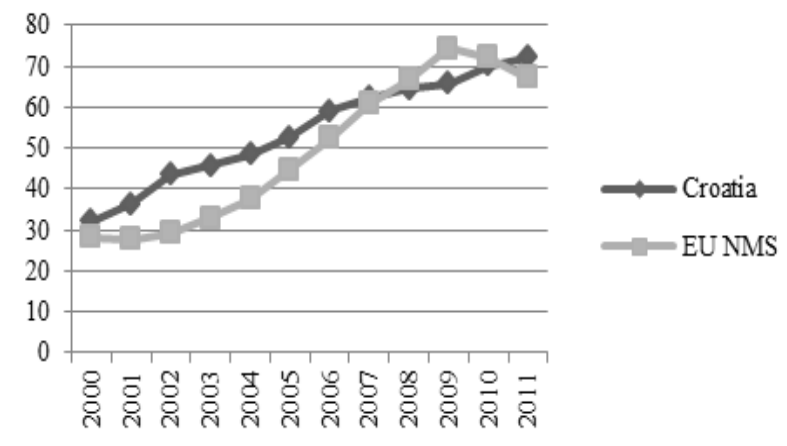

(a) Domestic credit to the private sector (\% of GDP)

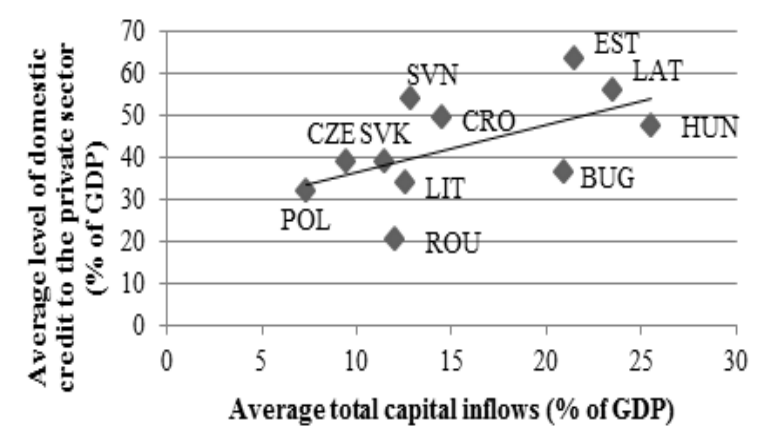

(b) Capital inflows vs. credit growth (2000-2008)

Source: World Bank - World Development Indicators, author's calculations Fig. 11. Relationship between capital inflows and credit expansion in Croatia and other EU NMS.

As mentioned earlier, the inflow of foreign capital played a key role in supporting high rates of economic growth in the pre-crisis period. In fact, the growth in consumption and investment has been supported by strong credit expansion of Croatian banks. Fig. 11a shows that the pre-crisis level of domestic credit to the private sector in Croatia has consistently been at a higher level than the average in EU NMS. In order to finance this credit growth, Croatian banks have turned to foreign sources, especially to their parent banks. Fig. 11b confirms a relatively strong relationship between capital inflows and the level of credit expansion in Croatia and other EU NMS. Countries with highest levels of average capital inflows in the 2000-2008 period, e.g. Estonia and Latvia, experienced the strongest credit growth, while in financially more closed countries, e.g. Poland, Czech Republic, or Slovakia, strong credit expansion was absent.

A significant increase in foreign currency lending to domestic agents who cannot hedge against the exchange rate risk, and which was financed by external borrowing by banks, has exposed the Croatian financial system to the indirect currency risk and to potential deterioration in asset quality of banks' balance sheets in the event of a significant depreciation of the kuna-euro exchange rate. Croatian banking system has inherited a high degree of currency substitution from the Yugoslav system, with the share of foreign currency deposits in total deposits reaching nearly 90 percent during the 1990s (Fig. 12). The share of foreign currency loans in total loans had fallen to about 10 percent until the early 2000s and the foreign currency deposits to foreign currency bank loans ratio fell below 12 percent in 2002. Such a currency mismatch between assets and liabilities in the consolidated balance sheet of the banking sector created a huge currency risk within the banking system since any substantial depreciation of the kuna would seriously endanger its stability.

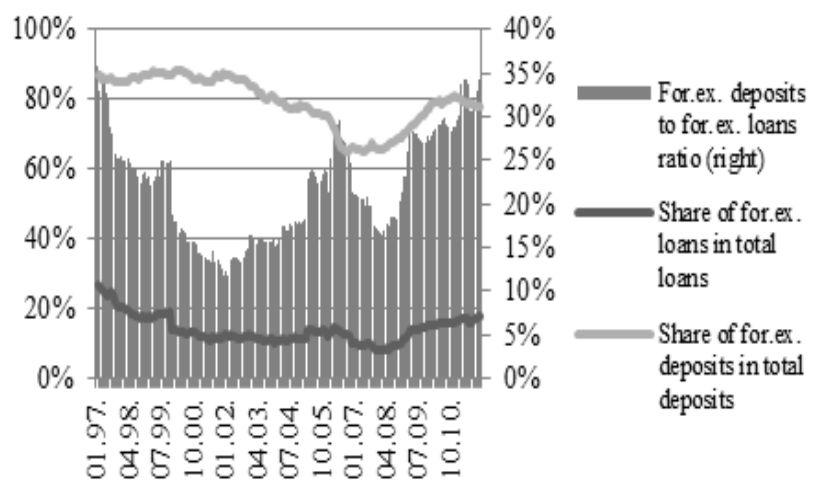

Source: CNB, author's calculations

Fig. 12. Currency mismatch in the consolidated balance sheet of Croatian banks, 1997-2011.

Optimistic expectations about future growth, followed by the growth of real GDP and lower risk aversion, have further strengthened the consumption- oriented credit expansion and become a threat to the macroeconomic and financial stability. Therefore, CNB responded to these developments by counter-cyclical, tightening restrictive monetary policy measures, limiting borrowing and imposing capital controls of Chilean type. Among administrative measures and sterilization instruments used by the CNB for the stated purposes were high reserve requirements, the imposition of minimum required foreign currency claims (to minimize currency mismatch between assets and liabilities - the success of this measure is shown in Fig. 12), the marginal and special reserve requirement (to limit banks' foreign borrowing), the mandatory purchase of treasury bills (to limit credit growth to 12 percent annually), and an increase in the minimum level of capital adequacy (for prudential reasons).

The above measures have made Croatian banking sector sufficiently capitalized and resilient to external shocks that followed in late 2008. A sudden stop in foreign capital inflows can have a very strong impact on the banking sector if it is largely dependent on foreign financing. Credit crunch, which is probable in such circumstances, would have an extremely negative impact on all sectors of the economy, and the ensuing economic downturn could have a negative rebound effect on banks in the form of deterioration of their balance sheets, increasing numbers of non-performing loans, reduced profitability and problems with maintaining the necessary level of bank capitalization [11].

After the onset in late 2008, the financial crisis began to spread around the world and seriously endanger banking systems in developed countries. The rumors that some Italian 
banks (owners of Croatian subsidiaries) came into serious difficulties have led to a considerable withdrawal of deposits from Croatian banks. Total savings and time deposits in Croatian banks decreased by HRK 3.9 billion in just three months - from September to December 2008 (Fig. 13).

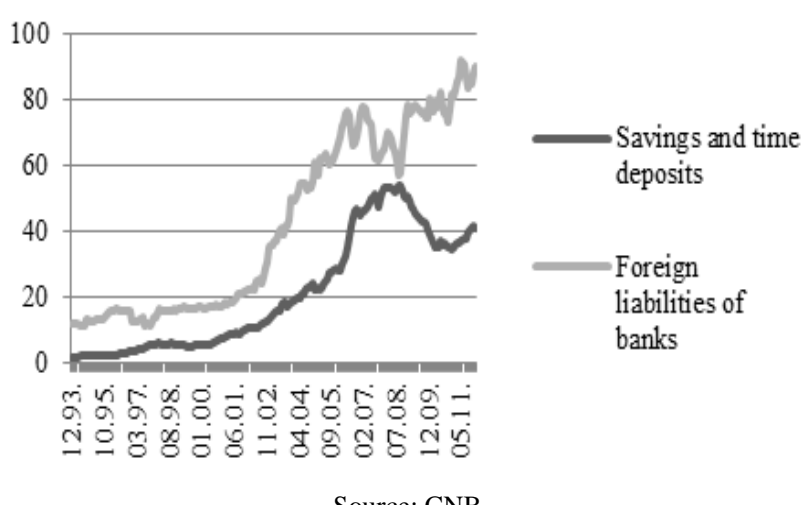

Fig. 13. Deposits and foreign liabilities in the consolidated balance sheet of Croatian banks, 1993-2011, in billions of HRK.

To compensate for the lack of funds, domestic banks turned to foreign parent banks and borrowed HRK 11.5 billion, and increased their foreign liabilities by HRK 17.7 billion (Fig. 13). The trend of deposit withdrawals from Croatian banks continued in the coming months, until late 2010 when bank savings started to grow again. At the same time, foreign liabilities continued to grow and they covered the resulting shortage multiple times, although the growth trend was somewhat slower in 2009 and 2010 due to a significant slowdown in domestic demand for loans. Inflows of debt capital from affiliated foreign banks to compensate for the lack of funds resulting from withdrawal of deposits and satisfying liquidity needs of the government in terms of the difficult access to foreign funds, significantly increased the external indebtedness of the banking sector. When all other sectors deleveraged, banks were the main creators of the newly formed Croatian foreign debt in 2008 (Fig. 6a).

In order to improve the liquidity of the domestic financial system and facilitate the inflow of capital to Croatian banks in terms of deposit withdrawals and lack of confidence in the banking sector, the CNB has significantly loosened the restrictive monetary policy and capital controls imposed in the pre-crisis period. The reserve requirement rate was reduced from 17 to 13 percent, and the rate of minimum required foreign currency claims was reduced from 32 to 20 percent. Furthermore, the marginal reserve requirement was completely abolished in October 2008. On the other hand, the rate of the minimum capital adequacy ratio increased from 10 percent to 12 percent in January 2009. By the described loosening of restrictive and prudential measures during the crisis, CNB released EUR 3.9 billion (approximately 8 percent of GDP) of the much-needed liquidity to banks and ensured the stability of the banking system [14].

The fact that the financial sectors in Croatia and in other EU NMS as well, still have a relatively low level of development and sophistication, i.e. a low market penetration of complex financial products and financial derivatives, with a small number of specialized financial intermediaries, has contributed to the preservation of the stability of the systems
[11]. Moreover, the dominance of foreign ownership of domestic banks ensured Croatian and other subsidiaries an access to the necessary funds in periods of low market liquidity. Furthermore, the exposure of foreign parent banks to subprime toxic assets, in most cases, has not proved to be problematic for their subsidiaries. On the other hand, the dominance of foreign ownership in the domestic banking market may pose a threat of capital flight, especially in terms of decreasing credit demand and worsening economic indicators. Until now, more pronounced flight of capital occurred in Romania and the Baltic countries [11], but by the end of 2011, none of the analyzed countries, including Croatia, have experienced a capital flight that would jeopardize the stability of the financial system.

\section{CONCLUSION}

This paper dealt with the implications of large capital inflows on macroeconomic and financial aspects of Croatian economy and those of other EU NMS. The research has shown that capital inflows benefited Croatian financial system by accelerating its development. However, they created several macroeconomic imbalances, e.g. fueled inflation, worsened the current account, increased the country's indebtedness and appreciated the real exchange rate, which created severe policy challenges when the crisis hit. The contribution of the paper lies in emphasizing the importance of differentiating between types of foreign financing, given that short-term debt flows provide more exposure to harmful macroeconomic and financial imbalances than long-term equity financing. This highlights the need for small integrated economies to create a new growth strategy based on attracting FDI in export oriented sectors, which are more likely to increase its growth potential in the long run.

\section{REFERENCES}

[1] B. Bosworth and S. M. Collins, "Capital flows to developing economies: implications for saving and investment," Brookings Papers on Economic Activity, vol. 30, no. 1, pp. 143-180, 1999.

[2] I. Ötker-Robe, Z. Polański, B. Topf, and D. Vávra, "Coping with Capital Inflows: Experiences of Selected European Countries," IMF Working Papers, no. 07/190, 2007.

[3] M. Blomström and A. Kokko, "Regional integration and foreign direct investment," WPS in Economics and Finance, no. 172, 1997.

[4] E. Borensztein, J. De Gregorio, and J.-W. Lee, "How does foreign direct investment affect economic growth?" Journal of International Economics, vol. 45, pp. 115-135, 1998.

[5] J. V. Hagen and I. Siedschlag, "Managing capital flows: experiences from central and eastern Europe," ESRI Working Papers, no. 234, March 2008.

[6] M. Pirovano, J. Vanneste, and A. Van Poeck, "Portfolio and short-term capital inflows to the new and potential eu countries: patterns, determinants and policy responses," University of Antwerp, Faculty of Applied Economics: Working Papers, no. 18, December 2009.

[7] R. Hausmann and M. Gavin, "The roots of banking crises: the macroeconomic context," Inter-American Development Bank Working Paper, no. 318, 1998.

[8] A. Lopéz-Mejia, "Large capital flows: a survey of the causes, the consequences and policy responses," IMF Working Papers, vol. 99, no. $17,1999$.

[9] Bank for International Settlements, "Capital flows and emerging market economies," CFGS Papers, no. 33, 2009.

[10] W. Buiter and A. Taci, "Capital account liberalization and financial sector development in transition countries," in Capital Liberalization in Transition Countries: Lessons from the Past and for the Future, A. 
Bakker and B. Chapple, Eds. Cheltenham, UK and Northampton, MA: Edward Elgar, 2003, pp. 105-144.

[11] S. Gardó and R. Martin, "The Impact of the global economic and financial crisis on central, eastern and South-Eastern Europe: A stock-taking exercise," ECB-Occasional Paper Series, no. 114, 2010.

[12] R. Jovančević, V. Arčabić, and T. Globan, "The consequences of global financial crisis on Croatian economy," in Proc. 4th Biennial Conf. of the AWBMMD: Conference Proceedings, Perth, 2010, pp. 525-540.

[13] T. Globan, "Privatizacija i ulazak stranog kapitala u hrvatski bankarski sektor," Grad. thesis, Faculty of Econ. and Bus., Univ. of Zagreb, 2008

[14] Ž. Rohatinski, "Ekonomska kriza i monetarna politika," presented at the Round table of Croatian Acad. of Science and Art, Zagreb, 2009.

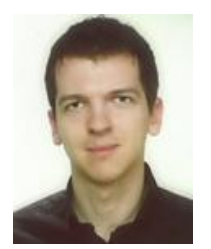

Tomislav Globan was born in Bjelovar, Croatia on September 3, 1986. In 2008 he graduated from the Faculty of Economics and Business at the University of Zagreb, majoring in finance. In 2013 he obtained a doctora degree at the Faculty of Econ. and Business in Zagreb. He has been employed as a teaching assistant since April 2009, and since July 2013 as a senior teaching assistant at the Dpt. of Macroecon. and Econ. Development, Faculty of Econ. and Business in Zagreb. He attended two international summer schools in the field of econometric methods at the Univ. of Cambridge and Univ. of Surrey (UK). He has so far published several scientific papers in the fields of macroecon. and international macroeconomics, and has participated in several international scientific conferences and scientific projects. Dr. Globan received a scholarship from City of Bjelovar and was awarded two Dean's awards for the success achieved during the study. He is a reviewer for the "Journal of Empirical Finance". 